\title{
NiO/YSZ Reduction for SOFC/SOEC Studied In Situ by Environmental Transmission Electron Microscopy
}

Simonsen, Søren Bredmose; Agersted, Karsten; Hansen, Karin Vels; Jacobsen, Torben; Wagner, Jakob Birkedal; Hansen, Thomas Willum; Kuhn, Luise Theil

\author{
Published in: \\ ECS Transactions \\ Link to article, DOI: \\ $10.1149 / 06402.0073$ ecst \\ Publication date: \\ 2014 \\ Document Version \\ Peer reviewed version \\ Link back to DTU Orbit
}

Citation (APA):

Simonsen, S. B., Agersted, K., Hansen, K. V., Jacobsen, T., Wagner, J. B., Hansen, T. W., \& Kuhn, L. T. (2014). $\mathrm{NiO} / Y S Z$ Reduction for SOFC/SOEC Studied In Situ by Environmental Transmission Electron Microscopy. ECS Transactions, 64(2), 73-80. https://doi.org/10.1149/06402.0073ecst

\section{General rights}

Copyright and moral rights for the publications made accessible in the public portal are retained by the authors and/or other copyright owners and it is a condition of accessing publications that users recognise and abide by the legal requirements associated with these rights.

- Users may download and print one copy of any publication from the public portal for the purpose of private study or research.

- You may not further distribute the material or use it for any profit-making activity or commercial gain

- You may freely distribute the URL identifying the publication in the public portal 


\title{
$\mathrm{NiO} / \mathrm{YSZ}$ reduction for SOFC/SOEC studied in situ by environmental transmission electron microscopy
}

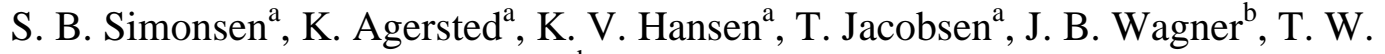 \\ Hansen $^{\mathrm{b}}$, and L. Theil Kuhn ${ }^{\mathrm{a}}$ \\ ${ }^{a}$ Department of Energy Conversion and Storage, Technical University of Denmark, DK- \\ 4000 Roskilde, Denmark \\ ${ }^{\mathrm{b}}$ Center for Electron Nanoscopy, Technical University of Denmark, DK-2800 Kgs. \\ Lyngby, Denmark
}

\begin{abstract}
A typical anode for solid oxide fuel cells (SOFC) or cathode for solid oxide electrolysis cells (SOEC) is a complex porous structure of Ni and yttria-stabilized zirconia (YSZ). The porous Ni/YSZ is usually prepared from powder mixtures of $\mathrm{NiO}$ and YSZ, tape casted and sintered into a dense structure and finally reduced during start-up of the SOFC/SOEC in $\mathrm{H}_{2}$ at the operating temperature of the cell (ca. $800{ }^{\circ} \mathrm{C}$ ). This contribution presents environmental transmission electron microscopy (ETEM) nanoscale observations of the reduction process of a $\mathrm{NiO} / \mathrm{YSZ}$ powder in $\mathrm{H}_{2}$ at temperatures up to almost $1000{ }^{\circ} \mathrm{C}$. The study focusses on the temperature dependent dynamical morphology of the $\mathrm{NiO} / \mathrm{YSZ}$ and on the possible influence of YSZ on the $\mathrm{NiO}$ reduction.
\end{abstract}

\section{Introduction}

The porous composite of $\mathrm{Ni}$ and yttria-stabilized zirconia (YSZ) is a state-of-the-art anode in commercial solid oxide fuel cells (SOFC) and cathode in solid oxide electrolysis cells (SOEC) (1-6). Here, Ni acts as both a catalyst and an electron conductor, while YSZ is the oxide ion conductor. The composite is porous to allow for gas diffusion to and from the active sites of the electrochemical cell, the so-called triple phase boundaries, TPBs. The porous $\mathrm{Ni} / \mathrm{YSZ}$ is typically prepared by sintering powder mixtures of $\mathrm{NiO}$ and $\mathrm{YSZ}$ $(3,4,6)$ into a dense structure which, is reduced during start-up of the SOFC/SOEC at ca. $800{ }^{\circ} \mathrm{C}$ to form the catalytically active Ni phase and the pores for gas transport $(3,5,6)$. The performance of an SOFC/SOEC depends on the reduction procedure $(2,7)$ and several studies have therefore addressed $\mathrm{NiO} / \mathrm{YSZ}$ reduction $(2,5,6,7,8)$.

One technique that has given significant insight into NiO reduction is ETEM (8-11), which offers spatial information with atomic scale resolution in a gas environment at elevated temperatures (12-15). For example, ETEM has been used to give insight into the initial $\mathrm{Ni}$ formation at the $\mathrm{NiO}$ surfaces (9). A recent study has addressed the reduction of a $\mathrm{NiO} / \mathrm{YSZ}$ composite at temperatures up to $500{ }^{\circ} \mathrm{C}(8)$.

The present study uses ETEM to monitor the dynamics of the reduction of a $\mathrm{NiO} / \mathrm{YSZ}$ powder sample in $\mathrm{H}_{2}$. The nanoscale dynamical changes of the $\mathrm{NiO} / \mathrm{YSZ}$ morphology are observed at temperatures from room temperatures and almost up to $1000{ }^{\circ} \mathrm{C}$. The evolution of the morphological changes is followed both at low $\left(4^{\circ} \mathrm{C} / \mathrm{min}\right)$ and very high $\left(1000^{\circ} \mathrm{C} / \mathrm{s}\right)$ temperature ramping rates. The temperature dependency of the 
reduction reaction determined from ETEM is compared to thermogravimetric analysis (TGA).

\section{Experimental}

An SOFC anode (or SOEC cathode) made from a mixture of $56 \mathrm{wt} \% \mathrm{NiO} / \mathrm{YSZ}$ (YSZ with $8 \mathrm{~mol} \%$ yttria) was prepared by tape casting and sintering $\left(1350{ }^{\circ} \mathrm{C}, 3 \mathrm{~h}\right)$ as described in detail in reference (16). In addition, a pure $\mathrm{NiO}$ sample was prepared by die pressing a pellet from the $\mathrm{NiO}$ powder and sintering it at the same conditions as for the $\mathrm{NiO} / Y S Z$ sample. The powder samples were prepared for TEM and TGA by grinding the sintered samples in a mortar.

ETEM was performed at $300 \mathrm{kV}$ using a Titan 80-300 (FEI) equipped with a differential pumping system (17). Here the samples were exposed to 2 mbar of $\mathrm{H}_{2}$ (AGA 6.0) while controlling the temperature with an Aduro 300 heating holder (Protochips Inc). Temperature calibration in 2 mbar $\mathrm{H}_{2}$ was performed by measuring the melting points of $\mathrm{Ag}$ and $\mathrm{Zn}$ nanoparticles. All samples were ground in a mortar with ethanol and mounted on thermal E-chips with carbon or SiN support film (Protochips Inc.).

According to a previous study, it is possible to reduce $\mathrm{NiO}$ in vacuum by using a focused $100 \mathrm{kV}$ electron probe (18). Before performing the actual reduction experiments, the possible artifacts induced by the electron beam were therefore determined in the following way: The $\mathrm{NiO} / \mathrm{YSZ}$ sample was exposed to $2 \mathrm{mbar}_{2}$ and a constant exposure to the electron beam with a beam current density of ca. $600 \mathrm{e}^{-} / \mathrm{nm}^{2} \mathrm{~s}$ for $30 \mathrm{~min}$ at room temperature. This treatment did not result in changes of the NiO/YSZ morphology, except from the formation of a layer of amorphous carbon on the sample surface. The reduction experiments were performed at approximately the same beam current density, but with a lower total dose. In addition, comparison of areas followed over time with unexposed areas showed no characteristic structural differences. It is therefore unlikely that the structural changes of the samples during the reduction experiments are dominated by effects of the electron beam.

For comparison with the ETEM results, thermogravimetric analysis (TGA) was performed on a Netzsch STA 409CD Thermo balance. After drying the samples at $150{ }^{\circ} \mathrm{C}$ for $2 \mathrm{~h}$, the temperature was ramped by $1{ }^{\circ} \mathrm{C} / \mathrm{min}$ to $1200{ }^{\circ} \mathrm{C}$ in a flow of 50 $\mathrm{Nml} / \min 9 \% \mathrm{H}_{2} / \mathrm{N}_{2}$ (Air Liquide: H4.6; N6.0).

\section{Results and discussion}

\section{$\underline{\text { ETEM results }}$}

$\mathrm{NiO}$ reduction at high resolution. An ETEM reduction experiment was performed in 2 mbar $\mathrm{H}_{2}$ at the constant temperature of $320{ }^{\circ} \mathrm{C}$ while acquiring high resolution images of the same region of the $\mathrm{NiO} / \mathrm{YSZ}$ powder sample every 10 second. Figure 1 shows three consecutive images from the image series. From these images the $\mathrm{NiO}$ and $\mathrm{Ni}$ phase can be identified from the characteristic lattice distances as indicated in the figure. From Figure 1 the growth of a Ni crystal in the surrounding $\mathrm{NiO}$ can be observed. Moreover, shrinkage of the $\mathrm{NiO}$ crystals is observed from the figure. 


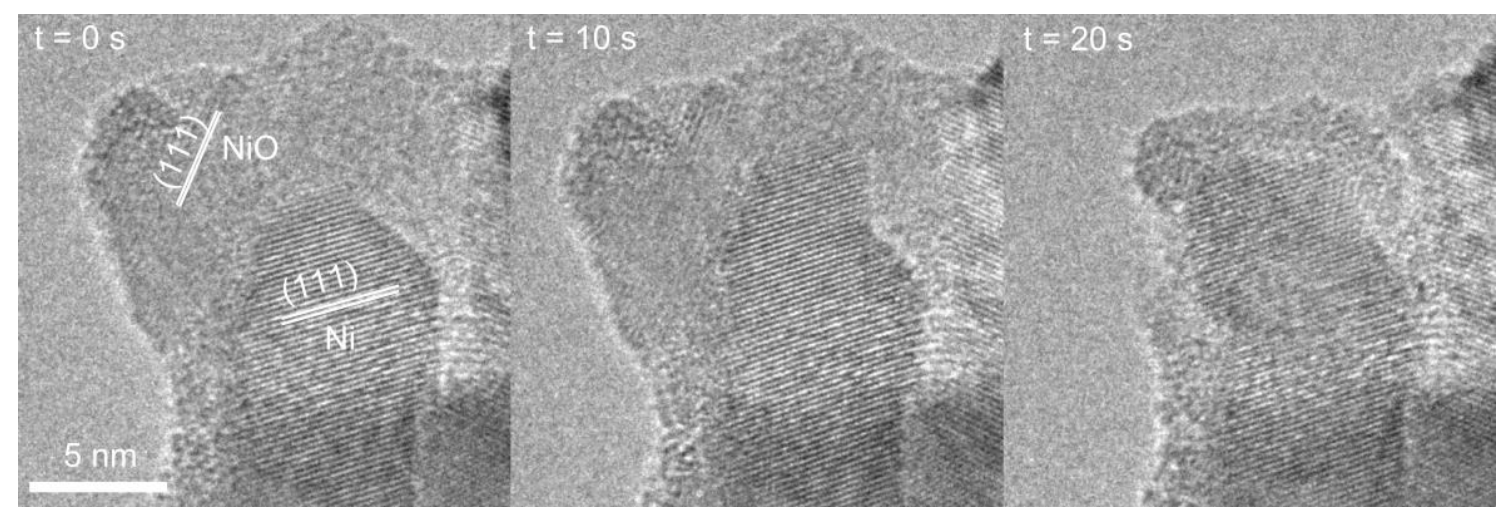

Figure 1. ETEM high resolution images of the same region of a $\mathrm{NiO} / \mathrm{YSZ}$ powder sample during exposure to 2 mbar $\mathrm{H}_{2}$ at $320{ }^{\circ} \mathrm{C}$. The $\mathrm{Ni}$ and $\mathrm{NiO}$ crystals and the time of acquisition are indicated in the figure.

The evolution of the NiO/YSZ morphology. To follow the overall morphology dynamics of the NiO/YSZ sample during reduction, another ETEM reduction experiment was performed while acquiring six images at lower resolution and at different temperatures of the same region of the $\mathrm{NiO} / \mathrm{YSZ}$ powder. In this experiment the gas pressure was also $2 \mathrm{mbar}_{2}$, but here the temperature was ramped by $4{ }^{\circ} \mathrm{C} / \mathrm{min}$. To minimize the artifacts from the electron beam during this relatively long experiment, the electron beam was removed from the imaged region in the time interval between image acquisitions.

The ETEM images from this experiment are presented in Figure 2. From these images the $\mathrm{NiO}$ and $\mathrm{Ni}$ phase cannot be identified directly as in the high resolution images as in Figure 1, and it is almost impossible to distinguish the $\mathrm{NiO}$ and YSZ grains in the first image recorded at room temperature. Instead, the reduction process can be followed from the dynamical changes in the $\mathrm{NiO}$ and $\mathrm{Ni}$ grain morphology while the morphology of the YSZ remains stable: initially, all grains are dense, but at $370{ }^{\circ} \mathrm{C}$ nanopores can be observed. The formation of pores during $\mathrm{NiO}$ reduction can be explained by loss of oxygen from $\mathrm{NiO}$, which theoretically leads to a volume decrease of $41 \%$. Previous studies of $\mathrm{NiO}$ reduction also have associated a porous morphology of the newly formed $\mathrm{Ni}(8,19,20)$. As the temperature is raised further, the morphology again changes by densification of the porous $\mathrm{Ni}$ and at $800{ }^{\circ} \mathrm{C}$ the $\mathrm{Ni}$ appears fully dense (Figure 2). Further coarsening and sintering of the Ni takes place from $800{ }^{\circ} \mathrm{C}$ to $970{ }^{\circ} \mathrm{C}$ (Figure 2) and at the last image in the series, the YSZ, which is stable at this temperature, can be distinguished from the Ni (Figure 2, $970{ }^{\circ} \mathrm{C}$ ).

This ETEM experiment shows that the reduction of $\mathrm{NiO}$ can lead to formation of $\mathrm{Ni}$ nanopores followed by densification. Furthermore, the Ni appears to be highly mobile at the nanoscale for temperatures $>800{ }^{\circ} \mathrm{C}$. These are the typical temperatures at which SOFCs and SOECs are operated and the TPBs are therefore most likely dynamic and will change structure during cell operation. 


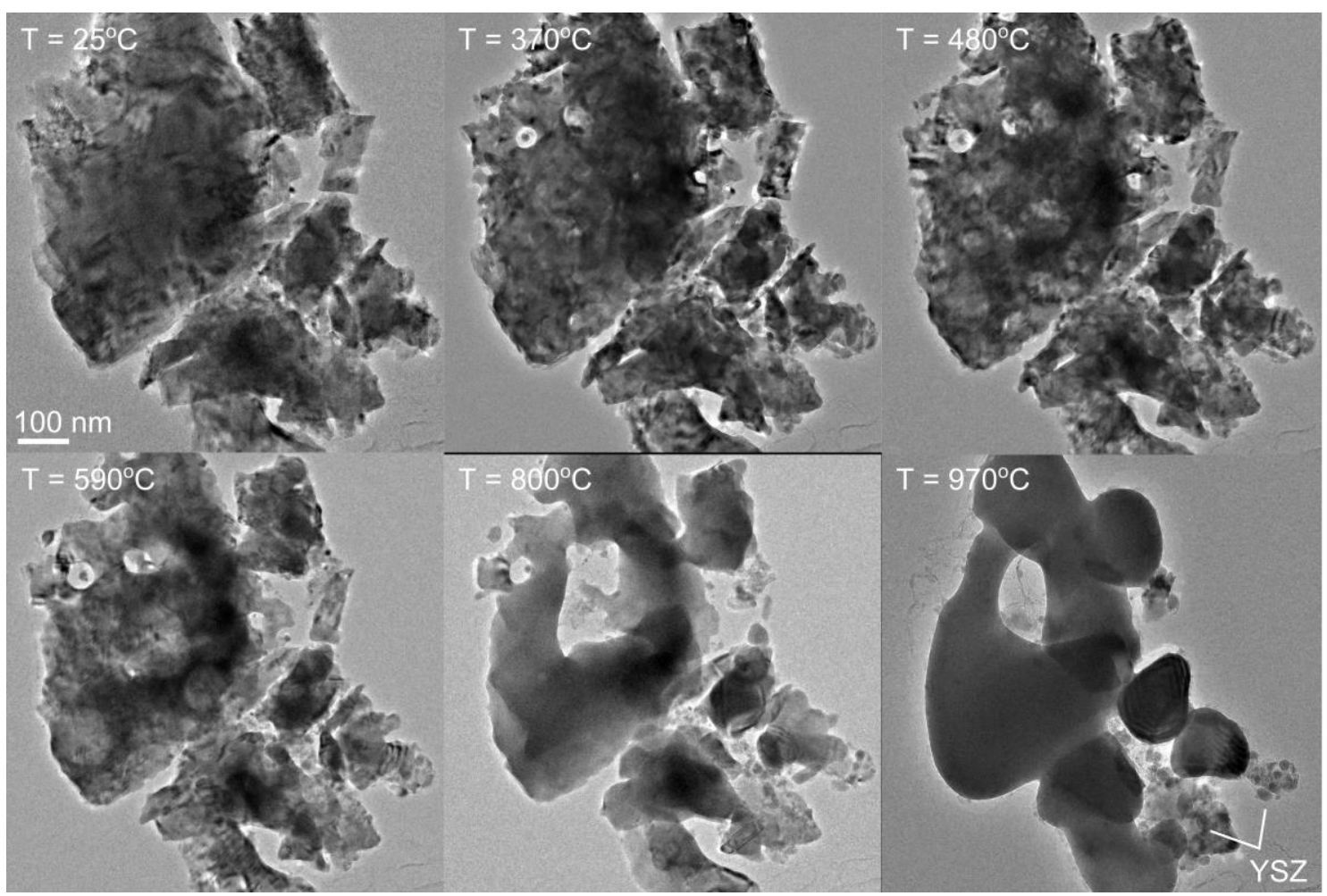

Figure 2. ETEM low resolution images of the same region of a $\mathrm{NiO}$ powder sample during exposure to 2 mbar $\mathrm{H}_{2}$ and constant temperature ramping rate of $4{ }^{\circ} \mathrm{C} / \mathrm{min}$.

Fast temperature ramping. One aim of the present study was to monitor the $\mathrm{NiO} / Y S Z$ reduction process at the typical operating temperature of an SOFC or SOEC (around $800{ }^{\circ} \mathrm{C}$ ). For the experiment presented in Figure 2, the pore formation resulting from the reduction process can be observed already at $370{ }^{\circ} \mathrm{C}$ while coarsening of the $\mathrm{Ni}$ is observed at higher temperatures. To study both the reduction and the morphology dynamics at the SOFC/SOEC operating temperature a reduction experiment with the very fast ramping rate of $1000{ }^{\circ} \mathrm{C} / \mathrm{s}$ from room temperature to $780{ }^{\circ} \mathrm{C}$ was performed. By using such a fast ramping rate, an almost instant change from non-reducing to a reducing environment at high temperature is obtained. This experiment could therefore be compared to a sudden shift in gas environment from inert to a reducing environment while maintaining a constant operating temperature.

Figure 3 presents ETEM images of the NiO/YSZ powder during exposure to 2 mbar $\mathrm{H}_{2}$, first at room temperature and then at $780{ }^{\circ} \mathrm{C}, 10 \mathrm{~s}$ and $20 \mathrm{~min}$ after initiating the fast temperature ramping, respectively (Figure 3 ). The morphology of the sample has changed already 10 seconds after the onset of the temperature ramp. No nanopores seem to develop during reduction when using the fast temperature ramp (Figure 3), contrary to the experiment with the slower ramping (Figure 2). After $20 \mathrm{~min}$ at $780{ }^{\circ} \mathrm{C}$ in $\mathrm{H}_{2}$, the $\mathrm{Ni}$ particles have obtained a more rounded shape as a result of the thermally activated $\mathrm{Ni}$ mobility (Figure 3)

This experiment shows that the $\mathrm{NiO}$ nanoparticles in a powder of $\mathrm{NiO} / \mathrm{YSZ}$ will reduce and become dense within seconds after switching to a reducing environment at the operating temperature of SOFCs/SOECs. The formation of nanopores are not observed for these small $\mathrm{Ni}$ particles which means that the dense $\mathrm{NiO}$ nanoparticles are either converted directly to dense $\mathrm{Ni}$, or that the lifetime of Ni nanopores is on a time scale of seconds or below due to rapid coarsening. 
For macroscopic samples, larger pores (micro-scale) are however observed after reduction in $\mathrm{H}_{2}$ at temperatures as high as $1000^{\circ} \mathrm{C}(1,19,20)$. This can be partly explained by the framework of YSZ surrounding the Ni for Ni/YSZ samples (1), but also for initially dense samples of pure $\mathrm{NiO}$, micropores have been observed in the $\mathrm{Ni}$ after reduction $(19,20)$. We suggest that the larger pores observed at high temperatures are due to collapse of the Ni nanopores and coarsening of the Ni particles. The voids surrounding the $\mathrm{Ni}$ particle resulting from the material volume shrinkage grow to form larger pores as the $\mathrm{Ni}$ is coarsening. The specific pore sizes obtained in the SOFC/SOEC will most likely influence the overall cell performance, since gas diffusion rates depend on the pore sizes (21).
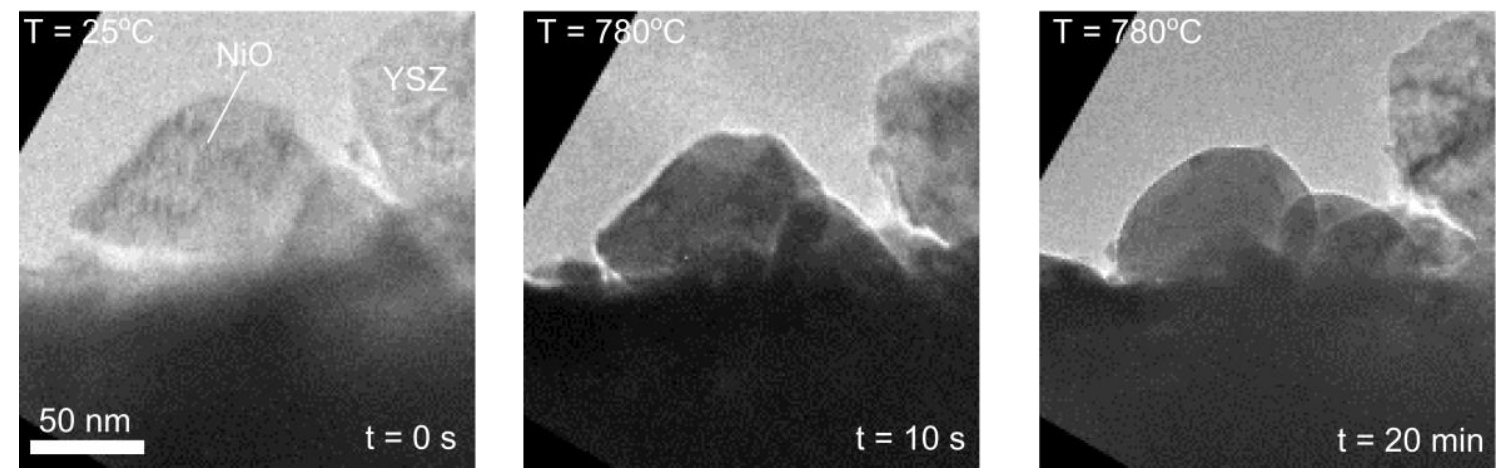

Figure 3. ETEM images of the same region of the NiO/YSZ powder during exposure to 2 mbar $\mathrm{H}_{2}$. The temperature is ramped by $1000{ }^{\circ} \mathrm{C} / \mathrm{s}$ from room temperature to $780{ }^{\circ} \mathrm{C}$ and held constant at this temperature, as indicated in the images.

The reduction temperature dependency. To quantify the degree of reduction from the ETEM images, an experiment was performed similarly to the one presented in Figure 2, but with a temperature ramping rate of $1{ }^{\circ} \mathrm{C} / \mathrm{min}$ and where images and diffraction patterns were recorded for every $10^{\circ} \mathrm{C}$. The non-porous areas (interpreted as $\mathrm{NiO}$ ) were measured as a function of temperature. Also, the powder diffraction patterns were circularly integrated and the normalized peak intensity of the $\mathrm{NiO}$ signal was plotted against the temperature. The image and diffraction analysis were fully consistent that the reduction of the $\mathrm{NiO} / \mathrm{YSZ}$ sample is initiated around $300{ }^{\circ} \mathrm{C}$ and that the reduction process is rapid between $300{ }^{\circ} \mathrm{C}$ and $400{ }^{\circ} \mathrm{C}$ in $2 \mathrm{mbar}_{2}$ and a temperature ramping rate of $1{ }^{\circ} \mathrm{C} / \mathrm{min}(22)$.

\section{$\underline{\text { TGA results }}$}

Since ETEM analysis offer very localized information compared to most other techniques, one inherent drawback is that only a very limited amount of sample is analyzed. In addition, to allow for electron transparency, TEM samples have thicknesses of up to only a few $100 \mathrm{~nm}$. For the present ETEM experiments this means that all observed grains have direct contact to the surrounding $\mathrm{H}_{2}$ gas environment. This situation is different from most studies of $\mathrm{NiO} / \mathrm{YSZ}$ reduction where averaging techniques, such as TGA $(2,4)$, thermomechanical analysis (TMA) (4), temperature programmed reduction (TPR) (1), X-ray diffraction (XRD) $(1,5,23)$, X-ray photoelectron spectroscopy (XPS) $(23,24)$ and Auger spectroscopy $(23,24)$ probe macroscopic samples. It is therefore a challenge to compare the present ETEM results directly with the reported results from such techniques and to determine whether apparent discrepancies could result from 
sample materials, experimental conditions or simply the difference in sample dimensions, geometry and related gas diffusion lengths.

To directly compare the ETEM results with an averaging technique, a TGA experiment was performed on the same batch of $\mathrm{NiO} / \mathrm{YSZ}$ powder sample and using the same temperature ramping rate as for the ETEM experiment. There are two experimental differences between the two experiments: a higher partial $\mathrm{H}_{2}$ gas pressure $\left(9 \% \mathrm{H}_{2} / \mathrm{N}_{2}\right)$ corresponding to $90 \mathrm{mbar}_{2}$ and a thicker and a larger amount of sample $(50 \mathrm{mg})$ in the TGA experiment.

The TGA experiment shows that the onset for reduction of the NiO/YSZ powder is ca. $280{ }^{\circ} \mathrm{C}$ and that full reduction is reached at ca. $800{ }^{\circ} \mathrm{C}$. A similar TGA experiment, but with a pure $\mathrm{NiO}$ powder showed reduction onset around $300{ }^{\circ} \mathrm{C}$ and a significantly higher reduction rate in the temperature range $300-400{ }^{\circ} \mathrm{C}$ as compared to the $\mathrm{NiO} / \mathrm{YSZ}$ sample (22). These temperature dependencies are consistent with results from previous studies where the differences were explained by the YSZ having an inhibitive effect on the $\mathrm{NiO}$ reduction $(1,2,6)$.

The temperature dependence of the NiO/YSZ reduction according to ETEM is significantly different from that of $\mathrm{NiO} / \mathrm{YSZ}$, but almost identical to that of $\mathrm{NiO}$ in the TGA experiment. An additional ETEM experiment on pure $\mathrm{NiO}$ showed that this was no coincidence: the reduction profiles of $\mathrm{NiO}$ and $\mathrm{NiO} / \mathrm{YSZ}$ are identical when the reductions are performed in the TEM (22). The comparison of the ETEM and TGA results therefore indicate that the YSZ only inhibits the $\mathrm{NiO}$ reduction reaction for macroscopic sample amounts, likely due to gas or mass transport limitations.

\section{Conclusions}

The reduction of $\mathrm{NiO} / \mathrm{YSZ}$ in $\mathrm{H}_{2}$ was investigated by ETEM where the conversion of $\mathrm{NiO}$ into $\mathrm{Ni}$ could be identified as a function of time or temperature from the characteristic atomic lattice spacings at high resolution and from pore formation at lower resolution. The reduction process was consistently quantified from the image analysis by measurements of non-porous sample areas and from the diffraction patterns by integrating peaks characteristic for $\mathrm{NiO}$. The reduction process was observed at temperatures between $300{ }^{\circ} \mathrm{C}$ and $400{ }^{\circ} \mathrm{C}$. At higher temperatures the $\mathrm{Ni}$ coarsened to become dense, with no visible nanopores at $800{ }^{\circ} \mathrm{C}$. At the fast ramping rate of $1000{ }^{\circ} \mathrm{C} / \mathrm{s}$ to $780{ }^{\circ} \mathrm{C}$, corresponding to an almost instant change from a non-reducing to a reducing environment, nanopores are not observed. The dense nanosized $\mathrm{NiO}$ grains appear to transform directly to a dense Ni state. TGA results show an inhibitive effect of YSZ on the $\mathrm{NiO}$ reduction, consistent with previous studies. The ETEM experiments on the other hand do not show such an inhibitive effect. The main difference between TEM and TGA experiments is the sample size. The observations therefore suggest that the inhibitive effect of YSZ observed from TGA is due to gas or mass transport limitations.

\section{Acknowledgments}

Karen Brodersen, DTU Energy Conversion is acknowledged for tape casting of the SOFC/SOEC samples. Lene Knudsen, DTU Energy Conversion is acknowledged for XRD measurements. Carsten Gynther Sørensen, DTU Energy Conversion is acknowledged for performing the TGA experiments. 
The A.P. Møller and Christine Mc-Kinney Møller Foundation is gratefully acknowledged for their contribution toward the establishment of the Center for Electron Nanoscopy in the Technical University of Denmark.

\section{References}

1. H. Mori, C. Wen, J. Otomo, K. Eguchi and H. Takahashi, Appl. Catal. A-Gen. 245 79 (2003).

2. D. Fouquet, A. C. Müller, A. Weber and E. Ivers-Tiffée, Ionics 8103 (2003).

3. N. M. Tikekar, T. J. Armstrong and A. V. Virkar, in Electrochemical Society Proceedings, S.C. Singhal and M. Dokiya, Editors, vol. 2003-07, p. 670, The Electrochemical Society Inc., Pennington, (2003)

4. D. Waldbillig, A. Wood and D. G. Ivey, Solid State Ionics 176847 (2005).

5. A. Hagen, H. F. Poulsen, T. Klemens $\varnothing$, R. V. Martins, V. Honkimäki, T. Buslaps and R. Feindenhans'1, Fuel Cells 5361 (2005).

6. N. M. Tikekar, T. J. Armstrong and A. V. Virkar, J. Electrochem. Soc. 153 A654 (2006).

7. S. L. Ebbehøj, T. Ramos and M. Mogensen, ECS Trans. 45363 (2012).

8. Q. Jeangros, A. Faes, J. B. Wagner, T. W. Hansen, U. Aschauer, J. Van herle, A. Hessler-Wyser and R. E. Dunin-Borkowski, Acta Mater. 584587 (2010).

9. Q. Jeangros, T. W. Hansen, J. B. Wagner, C. D. Damsgaard, R. E. DuninBorkowski, C. Hébert, J. Van Herle and A. Hessler-Wyser, 10th European SOFC Forum proceedings B0503 (2012).

10. S. Chenna and P. A. Crozier, Micron 431188 (2012).

11. R. Banerjee. P. A. Crozier, J. Phys. Chem. C 11611486 (2012).

12. R. T. K. Baker and P. S. Harris, J. Phys. E Sci. Instrum. 5793 (1972).

13. R. Sharma and P. A. Crozier, in Handbook of Microscopy for Nanotechnology, N. Yao and Z. L. Wang, Editors, p. 531, Klüwer Academic Publishers, Boston/Dordrecht/New York/London, (2005).

14. P. L. Hansen, S. Helveg and A. Datye, Adv. Catal. 50A 77 (2006).

15. B. Wagner, F. Cavalca, C. D. Damsgaard, L. D. L. Duchstein and T. W. Hansen, Micron 431169 (2012).

16. S. Ramousse, M. Menon, K. Brodersen, J. Knudsen, U. Rahbek, P. H. Larsen, ECS Trans. 7317 (2007).

17. T. W. Hansen, J. B. Wagner and R. E. Dunin-Borkowski, Mater. Sci. Technol. 26 1338 (2010).

18. E. C. Dickey, V. P. Dravid, P. D. Nellist, D. J. Wallis, S. J. Pennycook and A. Revcolevschi, Microsc. Microanal. 3443 (1997).

19. T. Hidayat, M. A. Rhamdhani, E. Jak and P. C. Hayes, Metall. Mater. Trans. B 40B 1 (2009).

20. T. Hidayat, M. A. Rhamdhani, E. Jak and P. C. Hayes, Metall. Mater. Trans. B 40B 474 (2009).

21. J. M. Thomas and W.J. Thomas, in Principles and practice of heterogeneous catalysis, p. 290, VCH, Weinheim, (1997).

22. S. B. Simonsen, K. Agersted, K. V. Hansen, T. Jacobsen, J. B. Wagner, T. W. Hansen and L. T. Kuhn, "Environmental TEM study of the dynamic nanoscaled morphology of NiO/YSZ during reduction", Submitted, 2014

23. J. A. Rodriguez, J. C. Hanson, A. I. Frenkel, J. Y. Kim and M. Perez, J. Am. Chem. Soc. 124346 (2002). 
24. R. P. Furstenau, G. McDougall and M.A. Langell, Surf. Sci. 15055 (1985). 